\title{
Incentives and political contributions*
}

\author{
DAVID JOULFAIAN \\ Office of Tax Analysis, U.S. Department of the Treasury, Washington, DC 20220 \\ MICHAEL L. MARLOW \\ Department of Economics, California Polytechnic State University, San Luis Obispo, CA 93407
}

\section{Introduction}

The growth of campaign spending over the past decade has attracted considerable attention. Recent studies have analyzed the impact of contributions on legislative vote patterns and the effects of campaign spending on election outcomes. ${ }^{1}$ This paper views political contributions as one form of voting and attempts to further our understanding of the determinants of individual decisions to contribute to political candidates.

Our information on individual political contributions is obtained from a new data set on individual income tax returns. Prior to the Tax Reform Act of 1986, and as early as 1971, the Internal Revenue Code allowed a dollar-for-dollar tax credit for contributions to political candidates and political groups. The ceiling on this credit was $\$ 50$ for single filers and $\$ 100$ for married filers. The fact that the price of giving is effectively zero implies that an individual's choice to contribute and take the tax credit is a "vote" in the political process. ${ }^{2} \mathrm{We}$ examine the relations between these political contributions, or "votes," and wealth, age, income tax rates and other relevant variables.

Our examination of political contributions provides empirical input into the voting-model literature. While most previous research examines political contributions and votes at highly aggregated levels (e.g., municipal, congressional, gubernatorial or presidential seats), our paper examines political contributions at the level of the individual. An advantage of examining individuals is that the study suggests which factors dominate an individual's decision to contribute and vote and therefore should be included in votingmodel examinations of the relation between contributions, votes and outcomes of elections.

*The views presented are those of the authors and do not necessarily represent those of the Treasury Department. 


\section{Political contributions: Data sources and testing specification}

Prior to 1987, the U.S. individual income tax allowed a dollar-for-dollar tax credit for contributions up to $\$ 50$ for single and $\$ 100$ for joint filers. Since the price is effectively zero, the decision regarding usage of tax credits is similar to the decision regarding voting. In both cases, the costs are similar and involve mainly time and information costs. In the case of voting, one must learn of the upcoming election, be registered and go to the poll. In the case of tax credits, one must pick his candidate(s), fill in the appropriate form, mail the check and then claim the credit on a tax return. The benefits of political contributions display characteristics similar to voting as well. The benefits to voting may be one's alignment with politicians of similar ideologies and with government policies that protect or enhance voters' wealth. Because tax credits convey benefits similar to voting, taking advantage of tax credits should yield similar benefits.

Our data on political credits are obtained from individual income tax returns, Form 1040. The data allow us to determine whether or not an individual opted for the tax credit, and, hence, has contributed to political candidates. Unfortunately, we cannot determine characteristics of fund-recipients; i.e., party affiliation or level of office (municipal, congressional, etc.) or the actual size of contributions when they exceed the tax credit ceiling. These issues, however, should not pose problems to our empirical work since we are not concerned with modeling the effects of these contributions on elections outcomes and political behavior. Rather, we are concerned with determining why taxpayers "vote" via contributions.

While individual tax returns contain information on income sources and can be used in deriving marginal tax rates, they are lacking in data on demographics and wealth. Therefore, we resort to a new data source that combines income and estate tax returns. This data set is based on a sample of estate tax returns of decedents in 1982 filed during 1982 and 1983. These estate tax returns were matched against the income tax returns for 1981. The match was successful for 6,212 tax returns. We eliminate divorced and separated inviduals in order to simplify our task of controlling for the influence of demography. This reduces the number of observations to 5,180 individuals with net worth ranging from $\$ 25,000$ to well over half a billion. ${ }^{3}$

We suggest the following testing specification of individual choice regarding political contributions: ${ }^{4}$

$$
\text { PC }=\mathrm{f}(\text { AGE, WEALTH, MARRIED, TAX RATE, REGION) }
$$

where, $\mathrm{PC}=1$ if political contribution are made; 0 otherwise 
Table 1. Logit regression results*

\begin{tabular}{lc} 
(Dependent variable $=1$ if individual makes a contribution) \\
\hline CONSTANT & -33.378 \\
& $(12.107)$ \\
$\ln (\mathrm{AGE})$ & 12.734 \\
& $(5.765)$ \\
{$[\ln (\mathrm{AGE})]^{2}$} & -1.547 \\
& $(0.686)$ \\
$\ln ($ WEALTH) & 0.254 \\
& $(0.049)$ \\
MARRIED & 0.909 \\
& $(0.074)$ \\
TAX RATE & 3.293 \\
& $(0.245)$ \\
DUMMY NORTHEAST & 0.058 \\
& $(0.091)$ \\
DUMMY MIDWEST & 0.187 \\
& $(0.088)$ \\
DUMMY WEST & 0.220 \\
& $(0.090)$ \\
Log of likelihood & -2872 \\
Sample size & 5810 \\
Number with contributions & 1341
\end{tabular}

*Standard errors in parentheses.
AGE = age of individual
WEALTH $=$ net worth
MARRIED $=1$ if individual is married; 0 otherwise
TAX RATE $=$ marginal tax rate
REGION = regional dummies for the Northeast, Midwest, and West.

To evaluate the effects of the above right-hand-side variables on the odds of contributing, we estimate a logit regression of (1). All of these variables are directly available on the tax returns with the exception of the marginal tax rate which is simulated. The simulation is performed by increasing the adjusted gross income by $\$ 100$ and simulating the change in tax liability through the return.

\section{Empirical findings}

Table 1 exhibits the logit estimation of (1), with the odds of contributing as a function of AGE, WEALTH, MARRIED, TAX RATE, and regional dummies. The results indicate that the odds of making political contributions rise 
with age and suggest that increases in political awareness are greatest in the early years of the life cycle. This suggests that the older the individual is, the greater is his interest in the system and, therefore, is more likely to contribute to political candidates. The sign of the coefficient of the squared log of age, however, indicates that the odds of contributing rise with age but at a declining rate.

The significant and positive coefficient for the log of WEALTH indicates that the odds of contributing rises with net worth. This suggests that wealth is an important determinant of an individual's interest in the political process.

The odds of contributing also rise with TAX RATE. Individuals in high marginal tax brackets are more likely to contribute than those in lower tax brackets. This result suggests that, given governmental income redistribution policies, individuals in high tax brackets face higher relative prices for government goods and, therefore, face greater incentives to participate in the political process via making political contributions. This result may also suggest that individuals not only vote at the polls with their "pocketbooks," but also contribute to politicians accordingly.

As for the dummy variables, MARRIED exerts positive effects on the odds of contributing. The signs on the coefficients of regional dummies suggest that individuals from the West and Midwest are more likely to contribute than individuals from the Northeast or the South.

\section{Conclusion}

Two implications from this research are noted. First, from a researcher's viewpoint, our research suggests the importance of age, wealth, tax rates, and marital status as determinants of political contributions by top U.S. wealthholders. Therefore, these factors should be included in aggregated models that attempt to analyze the relations between such variables as voting, campaign expenditures and the outcomes of elections. Second, from politicians' viewpoints, this research suggests that individual economic variables such as marginal tax rates and wealth are major determinants of individual decisions to contribute to politicians. Assuming that such contributions reflect "votes," this research suggests the relative importance of focusing campaign promises on economic variables - a strategy that "low tax" politicians like Ronald Reagan and George Bush may keenly be aware of.

\section{Notes}

1. See Jacobson (1984, 1985), Mablin (1984), Becker (1983), Chappell (1982), and Kau et al. (1982), Welch (1980, 1981), and Bental and Ben-Zion (1981). 
2. See Jacobson (1976) for a discussion of public funds for politicians.

3. A list of the variables and summary statistics are available upon request.

4. Riker and Ordeshook (1968) and Stigler (1971) argue that voting is a function of individual benefit-cost calculations. Many factors are candidates for inclusion into these calculations. Kau and Rubin (1979) argue that ideology enters into the calculation since contributors may support candidates with the greatest advocacy of their views about government policy. Others suggest the importance of "closeness of the race" (Riker and Ordeshook, 1968) and the costs of voter-information (Tollison, Crain and Paulter, 1975).

\section{References}

Becker, G.S. (1983). A theory of competition among pressure groups for political influence. Quarterly Journal of Economics 98: 371-400.

Bental, B. and Ben-Zion, U. (1981). A simple model of political contributions. Public Finance Quarterly 9: 143-157.

Chappell, H.W. (1982). Campaign contributions and congressional voting: A simultaneous probit-tobit model. Review of Economics and Statistics 64: 77-83.

Jacobson, G.C. (1976). Public funds for congressional candidates: Who would benefit? Public Policy 24: 1-32.

Jacobson, G.C. (1984). Money in the 1980 and 1982 congressional elections. In M. Malbin (Ed.), Money and politics in the United States. Chattam, NJ: Chattam House.

Jacobson, G.C. (1985). Money and votes reconsidered: Congressional elections, 1972-1982. Public Choice 47: 7-62.

Kau, J.B. and Rubin, P.H. (1979). Self-interest, ideology, and logrolling in congressional voting. Journal of Law and Economics 22: 365-384.

Kau, J.B., Canon, D. and Rubin, P.H. (1982). A general equilibrium model of congressional voting. Quarterly Journal of Economics 97: 271-293.

Malbin, M.J:. (Ed.) (1984). Money and politics in the United States. Chattam, NJ: Chattam House.

Riker, M.J. and Ordeshook, P.C. (1968). A theory of the calculus of voting. The American Political Science Review 62: 25-42.

Stigler, G.J. (1971). The theory of economic regulation. The Bell Journal of Economics and Management Science 2: 3-21.

Tollison, R.D., Crain, W.M. and Paulter, P. (1975). Information and voting: An empirical note. Public Choice 24: 43-49.

Welch, W.P. (1980). The allocation of political monies: Economic interest groups. Public Choice 35: $97-120$.

Welch, W.P. (1981). Money and votes: A simultaneous equation model. Public Choice 36: 209234. 